\title{
Towards Comprehensive Guidance for States in the African Region to respond to Children's Rights in Emergencies, Disasters and Pandemics
}

\author{
Nicole Bouah \\ LLM candidate, Department of Law, University of the Western Cape, \\ Cape Town, South Africa \\ 3643523@myuwc.ac.za \\ Julia Sloth-Nielsen \\ Professor, Public Law and Jurisprudence, University of the Western Cape, \\ Cape Town, South Africa \\ Professor, Children's Rights and the Developing World, Leiden University, \\ Leiden, The Netherlands \\ jsloth-nielsen@uwc.ac.za
}

\begin{abstract}
The Covid-19 pandemic spread has it impacted health systems, economies and communities across the African continent. It has also exacerbated risks already faced by children: limiting access to education, reducing protection from sexual and genderbased violence, harmful traditional and cultural practices including child, early or forced marriage (CEFM), female genital-mutilation (FGM); and further limiting access to reproductive services and food insecurity. This article illustrates that because demonstrably different considerations arise by comparison to children's experiences in the global north, it would be a valuable contribution for the African Committee of Experts on the Rights and Welfare of the Child to develop a General Comment on state responses to upholding children's rights in the context of epidemics, pandemics and emergencies, tailored to the specificities of the region.
\end{abstract}




\section{Keywords}

Africa - African Committee of Experts on the Rights and Welfare of the Child - right to education - right to nutrition - right to health - child protection

\section{Introduction}

On 11 March 2020, The World Health Organisation (wHO) declared the Coronavirus (COVID-19) outbreak a global pandemic (Cucinotta and Vanelli, 2020 ). African governments commonly responded in the form of a declaration of states of emergency, states of disaster and by introducing lockdowns (Akech, 2020: 585). While these measures reduced the spread of infection, it effectively limited certain human rights and thus set back decades of progress in achieving these fundamental freedoms (Plan International, 2020). As the CoviD-19 pandemic spread across the African continent, not only has it impacted health systems, economies and communities, but it has also exacerbated risks already faced by children: limiting access to education, reducing protection from sexual and gender-based violence, harmful traditional and cultural practices including child, early or forced marriage (CEFM), female genital-mutilation (FGM); and further limiting access to reproductive services and food insecurity. In one recent study based on interviews with care-givers and children, more than three in four households reported an income loss since the beginning of the pandemic. Poorer households were more likely to suffer income losses (82 per cent) than those not classified as poor (70 per cent). Urban households were also disproportionately affected by income loss, with respondents from urban areas almost twice as likely to say they have lost their job (61 per cent) compared with those in rural areas (33 per cent) (Save the Children, 2020: 6). 70 per cent of respondents in this study reported that they had received no additional financial support. Children on the street and those displaced as a result of natural disasters and civil strife were also at increased risk (UNICEF, 2O2O). In sum, in contexts in which there was already deprivation, CoviD-19 exacerbated vulnerability.

The Convention on the Rights of the Child, 1989 (CRC) is the most widely ratified international instrument which applies to all children under 18 in all contexts, including in emergency, pandemic and disaster situations. Many governments, in responding to COVID-19, have enacted legislation or decrees, and implemented measures which directly and indirectly impact a full range of child rights as set out in the CRC specifically: the right to education (Articles 
28, 29); right to information and to be heard (Articles 12, 13, 17); right to protection from violence (Articles 19, Article 34); right to life, survival and development (Article 6); right to an adequate standard of living (Article 27); right to non-discrimination (Article 2); right to birth registration (Article 7).

The African Charter on the Rights and Welfare of the Child, 1990 (ACRWC), is the regional human rights treaty which sets out the rights of children within the African context. ${ }^{1}$ The ACRWC also defines a child as a human being below the age of 18 years (Article 2). The following rights are impacted as a result of African governments responses to COVID-19: right to non-discrimination (Article 3); right to voice their opinion and views (Article 4, Article 7); right to life (Article 5); right to birth registration (Article 6); right to education (Article 11); the right of every mentally or physically disabled child to specific protection (Article 13); right to be protected from violence or abuse including sexual exploitation and sexual abuse (Articles 16, 27); right to be protected from harmful social and cultural practices such as child marriage (Article 21); right to receive appropriate protection and humanitarian assistance (Article 23).

Whilst many Charter rights find an equivalent in the CRC (eg the right to non-discrimination), some enjoy a superior formulation, providing added protection, such as in the case of children affected by armed conflict or child refugees, or have no CRC equivalent (Mezmur, 2020: 695 and sources cited there). In particular, and relevant to the discussion here, is that the Charter evidences special concern for the vulnerability of the girl child (on matters such as access to education for the girl child, harmful practices including female genital mutilation (FGM) and child marriage). Indeed, the very implementation clause (Article 1(3)) addresses the need to discourage 'any custom, tradition, cultural or religious practice' that is inconsistent with the 'rights, duties and obligations' incurred under the Charter. It is widely known that adverse aspects of patriarchy, culture and tradition disproportionately impact girls. Women's rights and the strive for gender equality are also articulated in a regional treaty, the Maputo Protocol to the African Charter on Human and Peoples' Rights, 2003, currently ratified by 43 of the 55 member states of the African Union.

This article will critically examine the measures adopted by various African governments in their response to combatting the CoviD-19 pandemic. It analyses the implications of such measures on the rights of children, particularly the girl child, and explores the challenges confronting children's rights in the Covid-19 era in African context against the backdrop of their legal obligations under the CRC and the ACERWC. It will aim to show the multidimensional

1 The African Children's Charter has now been ratified by 49 states parties, the most recent of which was the Democratic Republic of Congo in December 2020. 
impact of emergencies, disasters and pandemics on children within an African context. Under review will be the right to education, harmful cultural practices, access to sexual and reproductive health rights, access to basic health care, birth registration and nutrition. Rather than disparate and often counterproductive responses being adopted by individual States, it will be argued that there is a need for comprehensive guidance for African State Parties in the form of a General Comment from the African Committee of Experts on the Rights and Welfare of the Child as to how to respond (or how not to respond) before, during and in the aftermath of pandemics, disasters and emergencies.

Education systems across the African continent, as elsewhere, have largely been disrupted by the COVID-19 pandemic and this has simultaneously magnified disparities in childhood education by limiting the opportunities of many of the most vulnerable children to continue their education (United Nations, 2020: 2).

In an effort to limit social gatherings and the spread of the virus, countless African governments made the decision to shut down educational institutions (Kamga, 2020: 559). School closures were mitigated by a shift to remote education through radio, television and online methods. However, the lack of preparation of teachers and pupils, and an inability to continue education remotely for the vast majority of educational institutions which lack the IT facilities and capabilities were soon highlighted (Anifowoshe et al., 2020:4).

The closure of schools exposed huge inequalities in childhood education (Plan International, 2020 B: 18). A major problem which many governments faced is the gap between children from the upper to middle classes and those from lower income households (eLearning Africa, 202O: 3). While governments and schools have had to become creative in their innovations (Edtech), the success of online learning depends on accessibility to a digital device, a consistent and affordable internet connection, and a conducive learning environment (Paschal and Mkulu, 2020: 3). Crowded homes shared by many inhabitants, and urban slums which are endemic in Africa, all too frequently do not provide satisfactory learning spaces, even were the necessary digital devices are available.

Both the CRC and the ACRWC provide for the child's rights to education in peremptory terms (Article 28 and Article 11). In particular, the right to basic education must be assured (the theme of the 2014 Day of the African Child was directly related to the implementation of the right to education, insofar 
as it was entitled, "A child-friendly, quality, free and compulsory education for all children in Africa", underscoring the importance of education as a tool for development on the continent). Moreover, this right is not subject to progressive realisation, as the implementation standard in Article 1 of the Charter does not provide a "clawback" clause in a similar form to that contained in Article 4 of the CRC with respect to economic social and cultural rights (also the implementation clause). Hence, the standard required for the implementation of this right is that 'all appropriate measures' must be taken with a view to achieving 'full realization' of the right. Elements of this include the provision of free and compulsory basic education, the obligation to encourage the development of secondary education and progressively to make it free and accessible to all, and to make higher education accessible on the basis of capacity and ability by 'every appropriate means' (Article 11(3)(a)-(c)). These standards are supplemented by provisions requiring targeted measures to reduce school dropouts and encourage regular school attendance, and to take special measures to ensure equal access to education for female, gifted and disadvantaged children (Article 11(3)(d) and (e)) (Sloth-Nielsen, 2016: 163). The African Committee of Experts has yet to issue a definitive statement on the nature of the right to education; in a recent admissibility decision concerning the expulsion of pregnant girls from schools in Tanzania, the Committee noted that, 'The right to education that is being alleged to have been violated is an essential right for children, which has a long-lasting effect on the wellbeing of children', also highlighting its fundamental nature (Legal and Human Rights Center and Center for Reproductive Rights (on behalf of Tanzanian girls $v$ United Republic of Tanzania, 2020). In an earlier communication, the Committee said that ' $[\mathrm{r}]$ atifying States Parties undertake to take all appropriate measures, with a view to achieving full realisation of this right. Article 11(3) (a) requires in particular the provision of free and compulsory basic education, which necessitate the provision of schools, qualified teachers, equipment and the well-recognised corollaries of the fulfilment of this right" (Decision on the communication submitted by the Institute for Human Rights and Development in Africa and the Open Society Justice Initiative (on behalf of children of Nubian descent in Kenya) against the government of Kenya: para. 63), emphasising that the African Commission on Human and Peoples' Rights had held that the failure to provide access to institutions of learning would amount to a violation of the right to education under the African Charter on Human and Peoples' Rights (para. 64). The Committee found that by denying children of Nubian descent citizenship, there was a consequential violation of their right to education insofar as 'there is de facto inequality in their access to available educational services and resources'. This clearly suggests that the promotion of substantive 
equality is the requisite standard against which to measure state parties' fulfilment of their treaty obligations.

However, in the context of school closures, remote and online learning methods raise several questions and concerns as to the accessibility and inclusiveness of these approaches (Kamga, 2020: 559), and hence the degree of fulfilment of the State's immediately realisable international treaty obligations. First, a solely remote digital approach to education presumes that all children will have access to, and be able to utilise effectively, tech devices and online learning platforms (Akech, 2020: 598). Similarly, while governments were quick to launch educational programmes on radio and television stations, these methods were only accessible to those with access to these devices, in addition to electricity (eLearning Africa, 2020: 3). It has become increasingly clear that in order to embrace remote learning across the African continent, it is imperative that the digital and class divide be addressed (Mbulanheni, 2020: 1). Furthermore, for the majority of students, there was little to no prior experience in learning outside the classroom, thus they lacked the digital skills and found it difficult to adapt to it (eLearning Africa 3). As a result, many students were left unable to engage in remote learning or received little to no instruction, feedback or interaction with their teachers, who struggled with the same issues (Human Rights Watch, 2020: 2). When asked how much they were learning during school closures, more than eight in ten children polled by Save the Children said that they were learning little or nothing at all (Save the Children 202O: 49). Evidently, these alternative learning methods are ineffective and non-inclusive (Akech, 2020: 598).

Providing financial and instructive support for educational technological tools to address the digital inequalities in e-learning should have been the first critical step (Hanekom, 2020). Where families cannot afford to provide their child with the necessary digital resources and the learner is not equipped with digital literacy, then virtual classes become another obstacle in the learning process (Human Rights Watch, 2020:4). For many African students, their ability to engage in remote learning is thus dependent upon having access to internet-enabled smartphones or computers - which for most is considered a significant investment (Mbulanheni, 2020:2).

Another pressing concern is that young girls are particularly vulnerable and disproportionately negatively affected by the closure of schools (Plan International B, 2020: 18). Girls face unique barriers in continuing their education remotely. They are at a greater risk of dropping out of school due to financial barriers, families' preference for boys having access to online schooling resources and returning to school, in addition to having increased care-giving and domestic labour responsibilities imposed upon them (Plan International 
B, 2020: 7-8). Moreover, widespread school closures increasingly puts girls at risk of sexual violence, early pregnancy and child marriage which may lead girls to drop out of school, further entrenching gender gaps in education (Plan International B, 2020: 20). This initial learning crisis may consequently become a generational catastrophe as the COVID-19 pandemic may have triggered a wave of dropouts among adolescent girls. One organisation (Education cannot wait, established during the World Humanitarian Summit in 2016 by international humanitarian and development aid actors, along with public and private donors, to help re-position education as a priority on the humanitarian agenda), estimates that young and adolescent girls are twice as likely to be out of school in crisis situations, and that they face greater barriers to education and vulnerabilities such as domestic/gender-based violence when not in school (Educationcannotwait, 2020).

Moreover, children with disabilities have been excluded from online home learning and have effectively been left behind (McAleavy, Joynes, Gibbs et al., 2020: 8). Remote lessons on online learning portals through computers, tablets, smart phones or television programmes often lack accessibility features for children with disabilities (Duraku and Nagavci, 2020:3). Even when accessibility features are made available, they require assistive technology that is not readily accessible to many children in poorer households (Kamga, 2020: 571). Furthermore, without additional teacher support or interpreters, many children with disabilities may find it difficult to work independently (UNICEF, 2020 B:1). Thus, the shift to virtual learning without reasonable provision made to accommodate children with disabilities constitutes pervasive discrimination against these learners (Kamga, 2020: 571). As regards children with disabilities, both the CRC and the African Children's Charter provide special measure of protection: for instance, Article 13 (2) of the Charter enjoins states parties to:

ensure, subject to available resources, to a disabled child and to those responsible for his care, ... assistance for which application is made and which is appropriate to the child's condition and shall in particular ensure that the disabled child has effective access to training....

Article 23 (3) of the CRC speaks directly to the right of the disabled child to effective access to education.

Therefore, in sum, not only have the numerous African governments' responses to COVID-19 undermined the fundamental human right to education, but due to the enabling nature of this specific right, they have also directly impacted the realisation of other human rights (such as sexual and reproductive health rights and the right to nutrition, discussed further below). 
These governments' failures to uphold their responsibility to guarantee education through human rights treaties for every child in their region not only undermines the right to education, but has significant consequences for entire generations of children, especially young girls (United Nations, 2020: 3).

As the Save the Children study reports, children themselves have emphasised the need for schools to open with proper safety measures in place, and the need for increased opportunities to play during Covid-19 (Save the Children, 2020: 30).

\section{Harmful Cultural Practices that Challenge the Promotion of Children's Rights}

Harmful cultural practices are expressly provided for in Article 21 of the African Children's Charter, which requires state parties to take 'all appropriate measures to eliminate them' focussing in particular on those that are prejudicial to the health or life of the child, and those that are discriminatory on the grounds of sex or other status. The inclusion of this provision has widely been regarded as having been motivated by concerns about FGM, and similar practices affecting the girl child. Child marriage is addressed directly in Article 21(2) of the Charter, which forms the basis of a joint General Comment issued by the African Commission and the Committee of Experts on ending child marriage in 2017 which commences with the statement that:

The prevalence of child marriage and its impacts are a major concern on the African continent. Child marriage has a serious impact on the enjoyment of human rights and fundamental freedoms, particularly for women and girls and in recent years has attracted high-level policy interest in continental forums. Among others, this interest has been expressed through the adoption of an African Common Position and the African Union campaign to End Child Marriage in Africa. Child marriage is prohibited under regional African law (para. 1).

Previous health crises such as the Ebola epidemic have shown that decisions to close schools and reduce access to reproductive health information and services in order to contain the spread of infection, undermines the progress and strategies made to end child marriage (UNFPA and UNICEF, 2O2O: 2). The CoviD-19 pandemic threatens to do the same as it has exacerbated many of the interwoven social and economic factors that drive child marriage such as limited access to education, increases in sexual abuse and violence, including violence in the home, closure of safe houses and exacerbation of economic hardships (Plan International, 2020 B: 20). 
Families in communities with strong traditional gender norms may feel they have little alternative but to consider child marriage in order to reduce the number of household dependants, to shield girls from the stigma associated with pregnancy outside of marriage and to receive a dowry or other gifts in exchange (Plan International, $2020 \mathrm{C}: 4$ ). With the growing food and economic insecurity, in addition to the growing risk of sexual abuse and sexual exploitation, many parents have married their young girls off to men, often much older (Save the Children, 2020: 66). For example, in Kenya, it has been reported that economic difficulties such as job losses for parents, have driven many girls into forced marriages in exchange for cash and other gifts (Plan International, 2020 B: 22). Research shows that girls who drop out of education are more likely to be married off and, vice versa, those who are married are more likely to drop out than their unmarried peers (Plan International, 2020 B: 20).

Another concern is that as African governments shifted their focus to combatting the COVID-19 pandemic, young girls were not adequately protected from FGM (UNFPA-UNICEF, $2020 \mathrm{~B}: 1$ ). Of the 25 countries in Africa that have banned FGM, the challenge arises due to cultural and religious opposition, weak penalties for perpetrators, limited knowledge or acceptance of these laws and limited resources allocated to their implementation (Plan International, 2020 C: 4). COVID-19 response measures have exacerbated many of the drivers of FGM, such as social isolation, school closures and lack of law enforcement (Newey and Brown, 2020). Parents and guardians have taken advantage of the lockdown measures and school closures to subject girls to FGM (Plan International, $2020 \mathrm{C}: 4$ ). FGM is also considered as a predecessor to child marriage as it is seen as a rite of passage (Hodal, 2020). As a result of economic hardships brought about by COVID-19, performing FGM has become a means of income for some. For example, in Somalia, there has been an increase in FGM during lockdown - it is estimated that 290,0oo girls had been cut with a spike linked to the months of Ramadan (The Guardian, 18 May 2020). According to Plan International, 'Circumcisers [are] going door to door offering to cut girls stuck at home during the pandemic' (Plan International, 2020 B: 22). In Kenya, it was reported that lock-down measures provided an opportunity for FGM to be performed since government accountability systems were operating at minimum levels (Plan International, 2020 B: 22).

Fear of the virus and its accompanying economic hardships has led to a re-emergence of FGM in some rural communities (ORCHID PROJECT, 2020:1). It is thus important that FGM risk mitigation strategies be incorporated into COVID19 response plans and child protection (UNFPA-UNICEF, 2020 B: 1). Safe spaces for girls at risk of or who are survivors of FGM must be created; protection and support services should continue to be available (Reliefweb, 2020) and rescue 
brigades and public awareness programmes against FGM should not be halted throughout any pandemic, disaster or emergency (Plan International, 2020 B: 22). As most people are at home, awareness campaigns could be launched through television or radio stations in order to mobilise community members to be alert and report cases, in addition to providing details of various shelters that are open (Bhalla, 2020). A consultation mechanism should be created so that young girls can contribute towards the formation of an appropriate and effective response - from needs assessments to the design of interventions and the monitoring of effectiveness (Girls not Brides, 2020: 2). Responses and interventions should be comprehensive, cross-sectoral, address both immediate and long-term needs, in addition to the unintended consequences of lockdown measures on young girls. Thus, the lack of integration of FGM within the COVID19 response has left many young girls at risk of extreme violence as FGM not only impacts these girls both psychologically and physically, but sets back progress in their education and overall future (ORCHID PROJECT, 2020:5).

Gender Based Violence (G BV)

The gendered impacts of emergencies, disasters and pandemics and their tendency to increase GBV have been well-documented in regional crises such as the Zika, SARS and Ebola epidemics (UNICEF, 2020 C: 1). COVID-19 is no different in this respect, because as quarantine measures force many to stay at home, girls are at a heightened risk of G BV (Mittal and Singh, 2020:1). During the African Committee of Experts on the Rights and Welfare of the Child's themed Day of General Discussion on Sexual and Reproductive Health Rights, held on 17 March 2021, this was a consistent theme articulated by participants and experts from all corners of the continent. ${ }^{2}$ This not only threatens these girls' physical, psychological and reproductive health, but curbs their social, economic and educational development (UNICEF, 2020 C: 1).

Before the CoviD-19 pandemic even began, violence against girls was pervasive across the African continent due to the reality that harmful gender attitudes, roles and social norms sanction violence against young girls (Parry and Gordon, 2020: 8; Maputo Protocol to the African Charter on Human and Peoples' Rights, 2003). During epidemics, it is more difficult for young girls to receive sexual and reproductive health services as there is limited opportunities to distance themselves from their abusers and resources are directed towards containing the disease (Roberton, Carter, Chou et al., 2020: 901). Like

2 At the time of writing, a formal report of the proceedings is not yet available. 
the Ebola outbreak in West Africa from 2013-2015, protocols were not created to protect girls from violence during the outbreak, thus leaving many adolescent girls vulnerable (Onyango Resnick and Davis et al., 2019: 121). Lack of access to services (eg child protection services and services for survivors) was a consequence of lockdowns which forced child protection and case workers to stay at home.

Although girls are not mentioned eo nomine, both the CRC (in Article 19) and the African Children's Charter (in Article 16) provide expansive guidance in requiring the establishment and maintenance of systems for responding to, investigating and following up on reports of violence and abuse. In addition, the CRC Committee released General Comment No. 13 on Violence Against Children in 2011 (CRC Committee, CRC/C/GC/13) in which the prevalence of violence in the home is explicitly identified:

the Committee also recognizes that the majority of violence takes place in the context of families and that intervention and support are therefore required when children become the victims of hardship and distress imposed on, or generated in, families (PARA. $3(\mathrm{H})$ ).

In turn, the Africa Committee of Experts adopted General Comment No. 5 in 2019, on General Measures of Implementation and systems strengthening for child protection. This document underscores the Committee's emphasis on the promulgation of child protection legislation, domestic violence legislation and anti-trafficking legislation (para. 5.3.1), including the adoption of an array of measures permitted to enable children to engage effectively with a child-sensitive justice system, such as child helplines.

Therefore, African leaders need to declare and recognise $\mathrm{GBV}$ as a pandemic in itself (Care, 2020: 6). For example, in June of 2020, President Ramaphosa of South Africa declared the femicide and GBV spike to be South Africa's second pandemic (Dlamini, 2020:6) This "shadow pandemic" or "twin pandemic" occurring alongside CoviD-19 across the African continent underscores the need during any pandemic, epidemic, disaster or emergency, for GBV protective services and interventions to be classified as 'essential' (Care, 2020: 6). This would include ensuring that child hotlines, safe spaces, sexual and reproductive health services, referral pathways and justice mechanisms remain open (Care, 2020: 9). As hospitals and clinics have shifted their focus to CoviD-19 infected patients, the health sector should work together with gender-violence organisations in order to update their referral pathways and delivery of services, albeit in different formats or locales (IFRC, 2020: 6). There is a need to prioritise the tools and methodologies for the prevention of GBV and to address its 
accompanying services to deal with the related psychosocial and health needs of affected young girls, and for these to be integrated into national emergency interventions (Egbulem, 2020).

Then there is a need to facilitate access to information to young girls and allow for meaningful opportunities of participation in decision-making concerning the design of programmes and policy design in order to ensure that GBV prevention and response can be carried out in a context-specific and sustainable way (Care, 2020: 9). While girls with access to technology can be reached through a national messaging system, bearing in mind the digital divide amongst adolescent girls, information must be available through other avenues as well, taking into consideration language, literacy and restricted movement (UNICEF C, 202O: 3-4). Information could be spread through radio broadcasts, or where possible delivered door-to-door while maintaining social distancing measures (UNICEF, C: 2O2O: 4).

Access to Nutrition in the Context of Schools Closures, and to Early Childhood Development

The child's right to nutrition, to life survival and development, and to an adequate standard of living are well articulated in international and regional treaty law (Article 6, 18(2) and 27 CRC; Articles 5 and 20 ACRWC). Article 2O(2) of the latter instrument is instructive insofar as reiterates the stance that parents and other persons responsible for the child are the primary agents responsible for the upbringing and development of the child, but that where they cannot fulfil this due to incapacity, eg as a result of poverty, states parties are required to step in to provide material assistance to parents and other persons responsible for the child, including (and particularly) with regard to nutrition, health, education, clothing and housing (Sloth-Nielsen 2016: 188). This duty implicates the school feeding schemes which are intended to mitigate the results of parental incapacity to provide for their child, as addressed in this section.

In West Africa, the Ebola crisis increased food insecurity more in the regions with high pre-existing levels. Analysis of data from the Liberian Household Income and Expenditure Surveys from 2014 and 2016 shows that households with children aged $5^{-18}$ in counties with a high Ebola prevalence were more vulnerable in 2014 at the beginning of the crisis, accounting for most of the food insecurity in the country, and that this situation worsened post-crisis. By 2016, the counties with high Ebola prevalence accounted for an even larger percentage of the total households experiencing food insecurity in the country, 
even though overall, levels of food insecurity dropped in the same time frame (UNICEF, 2O2O: 9). Food insecurity is an enduring consequences of pandemics, it seems.

On 28 January 2021, UNICEF and the World Food Programme (WFP) released a report stating that more than 39 billion in-school meals have been missed globally since the start of the COVID-19 pandemic due to school closures. The Report, "CoviD-19: Missing More Than a Classroom", notes that 370 million children worldwide - many of whom are reliant on school meals as a key source of their daily nutrition - have missed 40 per cent of in-school meals, on average, since COVID-19 restrictions shuttered classrooms (UNICEF C, 2020).

In EqualEducation and others v. Minister of Basic Education (case 22588/2020), a class action lawsuit was brought in South Africa against the Minister relating to the National School Nutrition Programme (NSNP), which had provided a daily meal to all qualifying learners. This scheme had ceased during the school closure period occasioned by COVID-19. COVID-19 had the devastating effect of denying 9 million school-going children, at 20 ooo schools, at least one nutritious meal a day, leaving many, many children hungry and unfed while attempting to learn (para. 20). The evidence of the amicus curiae was that an estimated 30 per cent of the South African population experience severe levels of food insecurity - a far higher rate than the global average or even the average for Africa (para. 30). Although feeding schemes were implemented by Government, and after two months of lockdown the Government stated that 788 .ooo food parcels had been delivered, it is undisputed that the NSNP would have on its own provided 45 million meals to children per week - rendering the generous estimate of 788,000 food parcels for the country as a whole bleak in comparison (para. 24).

The applicants argued that the provision of basic nutrition was part and parcel of the constitutionally guaranteed right to basic education. When schools initially reopened for the final year of primary school and the final year of High School, it was announced that the NSNP would only be available to learners in those grades, stating that it would only be rolled out to learners in other grades in a phased way.

In the words of the Director General of Basic Education,

[w]here it was implemented, the Programme was shown to improve punctuality, regular school attendance, concentration and the general well-being of participating learners. Whilst learners were being provided with nutritious meals, they were taught to establish and maintain good eating and lifestyle habits for life. Nutrition education also provided educators with resource materials to support the curriculum and to make every school a healthy school (PARA. 18). 
The Gauteng court held that the Department's own policy statements reflected basic nutrition as component to basic education, the two being inextricably linked. 'The Minister ... cannot take away the pre-existing right of basic nutrition of at least a meal a day during school terms'. Any deliberate retrogressive measure needs to be fully justified upon careful consideration with reference to the totality 'of the rights provided for in the Covenant and in the context of the full use of the maximum available resources' (paras. 45 and 57, alluding to the UN Committee on Economic, Social and Cultural Rights General Comment No. 3 para. 9 and to CRC Committee General Comment No. 19 (on public budgeting for the realisation of children's rights, CRC/C/GC/19), in particular the injunction that retrogressive steps can only be taken when all other options have been considered).

Section 28(1)(c) of the South African Constitution, 1996, grants children the right to shelter, to basic nutrition, basic health care services and social services. Stating that children's constitutional rights pertaining to basic nutrition are not subject to internal limitation or to progressive realisation, the Court found that the so-called "phased in" approach was a violation of children's constitutional rights, without justification. A supervisory interdict was issued, to enable the court to monitor compliance, ie that the Department resume the NSNP for all qualifying learners.

Subsequently state nutritional support to children arose in another South African case, sA Childcare (Pty Ltd) v. Minister of Social Development and others (case $36962 / 2020$ ) concerned a challenge to directives issued relating the closure of early child development (ECD) facilities and the non-payment of state subsidies, one component of which concerns nutrition, to these institutions under Covid 19 lockdown. The court held that:

[t]he hardship caused by the Covid 19 lockdown regulations on indigent vulnerable young children attending ECDs is unimaginable. ECDs cater for the needs of babies and children until school going age. Most of the children attending ECDs live in the poorest of circumstances. Their parents are either absent or if present do not have the financial means to care for the children's nutritional and stimulation needs. Without ECD s these children are left without nutrition in, for the most part, a socially unstable and perilous environment. ECD s were closed at the end of March 2020 in accordance with the Alert Level 5 lockdown regulations. Their closure led to thousands of poor children being without food or proper care. Once the country moved to Alert Level 4, the struggle to re-open ECDs has been fought bitterly and on a continuous basis (PARA. 4). 
The non-payment (or withholding) of the subsidies meant that children attending ECD centres, once they received permission to re-open, could not be fed, nor could care-givers at the centres be paid. As stated by the judge, without subsidies the Centres could not re-open, and without re-opening, they could not requalify for the subsidy - a cart and horse situation (para. 36). The Minister was placed under a structural interdict, to be monitored by the Court, requiring her to ensure without delay that the subsidies be paid to approved ECD s to allow them to function,

so that they may provide nutrition and stimulation to infants and young vulnerable children, thereby promoting the rights of children to life, nutrition, social services, education and the enhancement of their development, whether they are attending qualifying ECD facilities or merely collecting food as a result of the COVID-19 pandemic (PARA. 39.8).

Children's right to basic health care is well provided for in article 24 CRC and Article 14 ACRWC. They include an emphasis on primary health and on preventive measures. Both these dimensions appear to be imperilled during epidemics such as COVID-19.

Disruptions in healthcare service provision were mainly due to diversions of health care resources to combating the pandemic. For instance, in November 2020 it was reported that measles campaigns had been suspended in 27 countries and polio campaigns put on hold in 38 countries, exposing at least $8 \mathrm{o}$ million children under one-year old to the risk of diseases such as diphtheria, measles and polio (Plan International B, 2020). Sierra Leone reported its first case of polio in December 2020, and as at February 2021, eight cases had been detected (https://polioeradication.org/where-we-work/sierra-leone/). Transport to health care facilities was affected, and treatment for chronic illnesses other than CoviD-19 were deprioritised. Mental health services and those addressing gender-based violence were perceived to be limited or unavailable (Saks et al. 2020: eoo3042). Costs of healthcare increased while household income reduced. Health workers, having been deployed to fight community transmission of COVID-19, were also less available (WHO, 202O). The medium- to longer-term impact of the cessation of essential primary health care services such as vaccinations cannot be predicted, but are likely to be serious if outbreaks were to occur as a result. Hence, State parties need to 
be reminded of the essential need to ensure continuation of basic health care services for children, even during other health crises.

\section{Access to Sexual and Reproductive Health Services}

The provision of family planning and other sexual and reproductive health commodities, including menstrual health items, are central to women's health, empowerment and sustainable development, and may be impacted as supply chains undergo strain from pandemic responses (UNFPA, 2020; Maputo Protocol, 2003: Article 14). Many organisations providing sexual and reproductive health services were forced to close (Plan International B, 2020), meaning that girls were forced to carry unwanted pregnancies or risk unsafe back street abortions. Access to contraceptives was also severely disrupted. For girls who were provided with personal and menstrual hygiene materials through school programmes, the school closures left them unable to observe essential menstrual hygiene. School closures mean that girls are more likely to be forced to engage in sexual activity than before, hence also more likely to get pregnant.

Therefore, maintaining access to these services during pandemics and emergencies is vital to ensure the protection of girls' rights for the medium and longer term. Innovative ways of service delivery needs to be devised in situations of isolation or confinement, such as teleservices, and school or community "drops" of reproductive health commodities, such as menstrual hygiene products and contraception. The dire need for continued access to sexual and reproductive health goods and services was highlighted by panellists from the continent at the General Day of Discussion on Sexual and Reproductive Health convened by the Africa Committee of Experts on the Rights and Welfare of the Child during March 2021.

\section{Birth Registration}

In Africa, nearly one in two children are deprived from a legal existence, despite the provisions of Article 7 CRC and Article 6 ACRWC which make birth registration of children compulsory. Countries such as Algeria and Tunisia top the list of countries that have impressively reached the targeted 100 per cent of birth registration. The trend of increasing registration of children at birth is also reflected in West and Central Africa, where over the past three years, the regional average of children under-five registered, increased from 45 per cent to 53 per cent, equalling up to 8.6 million more children registered. 
These statistics reveal that the continent has in recent years made considerable progress in improving birth registration. However, that improvement only accounts for $5^{2}$ per cent of children under-five registered in Africa, leaving millions of other children deprived of their basic right to a legal identity. In Eastern and Southern Africa, the average percentage of children under five registered is currently 40 per cent. Unless progress is accelerated, the total number of unregistered children in Africa will continue to increase and will exceed 110 million by 2030 (63 per cent).

With the prevention and containment measures against the CoviD-19 pandemic such as lockdowns and restrictions, birth registration centres and service points have reduced the availability and accessibly of services. In South Africa, it was estimated that under lockdown level 5, 100,00o births went unregistered (Zuzile, 2020). The new realities threaten to reverse the accumulated gains and decelerate the evident progress to be on track with the aspirations of Agenda 2063 and the global Sustainable Development Goals.

Birth registration continues to be an African Union priority. It is regarded as one of the key elements to accelerate social justice for any person, from birth all through their lifecycle. The African Union has emphasised the need to prioritise and classify civil registration as an essential service, and highlighted the need for cross-cutting strategies to ensure business continuity during emergencies, including pandemics such as CoviD-19, and other disruptive public health emergencies and disasters (African Union 2020). Practical solutions could include civil registration offices preparing contingency plans to meet post-pandemic demand and any pent-up backlog for birth registration. Late registration fees and penalties could be waived for a given period of time, and measures with facilities such as mobile registration centres, expansion of staffing, and creating awareness of availability of services could be enhanced to further this goal (African Union, 2020). Pandemics and disasters should not ultimately have the effect of reversing social development gains already made in Africa, and this needs to be highlighted to States who are faced with emergencies or pandemics.

\section{$9 \quad$ Proposals for Comprehensive Guidance}

The African Committee of Experts on the Rights and Welfare of the Child (the body which monitors the implementation of the African Charter on the Rights and Welfare of the Child), issued, among others, a Guiding Note to Member States of the African Union ( $\mathrm{AU}$ ) on measures to be taken to uphold children's rights during the COVID-19 outbreak (ACERWC, 202O). This Guiding Note of 
6 April 2020 describes the reality of the ramifications of the pandemic for African children thus:

[The ACERWC would like to] stress the fact that beyond its immediate impacts on children health and that of their parents or caregivers, the social and economic disruptions caused by the outbreak also harms children's rights and welfare ... Millions of others are "temporarily" out of school due to the CoviD-19, with the risk of permanent drop out, especially of children in vulnerable situations, such as, inter alia, the girl child, children with disabilities, children who belong to economically disadvantaged parents and children living in rural areas to mention but a few.

The pandemic is likely to result in a devastating effect on family functioning by limiting sources of income for households, resulting in limited access to adequate nutritious food, health care, appropriate shelter and other basic needs, which will then have an immediate and longer-term consequences on the life, survival and development of children.

The Guiding Note contains a series of extremely practical and concrete recommendations to African governments. These include: the provision of information to children (about handwashing, for instance) in child friendly language and formats that they can understand, having due regard to their evolving capacities; establishing child friendly quarantine procedures and environments, with due regard to the availability of food and potential heightened risk of depression and anxiety; ensuring every child's right to education (noting that the provision of school meals might also be compromised by school closures); urging Member States to create platforms to facilitate tailored learning activities at home for children, drawing on UNESCO guidance; ensuring the continued provision of essential services which are crucial to life, survival and development of children, such as essential health services, essential neonatal care, treatment of severe diarrhoea and pneumonia, and immunisation programs, which should not be interrupted.

The ACERWC points out further that, during the pandemic, access to services for pregnant women, women in labour and delivery, and lactating women is negatively impacted:

To address the particular challenges that pregnant and lactating women may face during the pandemic, Member States should ensure that all women have access to safe birth, antenatal and postnatal care. In this regard, Member States may consider deployment of house to house 
pre-natal health service and delivery with assistance of hotlines to help locate mothers. Similarly, Member States should also maintain access to sexual and reproductive health and rights (SRHR) information and services for adolescent children.

These are but a sample of the recommendations and advice provided in the Guiding Note, which also identifies particularly vulnerable groups of children (such as separated children and children in alternative care).

However, as pointed out below, a Guiding Note lacks legal specificity, nor does it even have the weight of "soft law" in international law terms. Furthermore, without any enhanced status as an official policy document, it risks being relegated to the "basket" of press releases and forgotten.

More recently, in February 2021, a call was issued for bidders to provide technical support to the Committee to undertake a Continental Assessment on the Impact of CoviD-19 on the Rights and Welfare of Children in Africa, to develop and facilitate the deployment of a tool to monitor the situation of the rights and welfare of children in the context of the pandemic; and to develop a template for Member States Reports on ACE RWC Guiding Note on COVID-19 (amongst others). ${ }^{3}$ The overall objective of the service is described as being 'to assess the impact of COVID-19 on the Rights and Welfare of Children in Africa. The assessment shall facilitate the collection of information on and analysis of the nature of the impact of the pandemic on children in AU Member States.'

Welcome though this data collection project might be, we argue that it, too, falls short of leading to a more authoritative road map for State parties. This leads to the proposal for the issuance of a General Comment on the responsibilities of States Parties during emergencies and pandemics by the ACERWC.

It is undeniable that not only has the impact of CoviD-19 been differently experienced in the African continent by comparison to other more developed regions. There is at the same time a need for a regionally specific, more comprehensive, and more authoritative, quasi-binding statement which provides an appropriate international law framework, building on previous Committee practice in developing General Comments.

The 'highly authoritative character' (Alston in Gerber 2013: 14) of General Comments, based on the provisions of the Convention, is recognised in international law in Article 31 of the 1965 Vienna Convention on Law of Treaties, stipulating that treaties need continuous contextual interpretation. A General

3 The author obtained the term of reference from the commissioning agents in February 2021. The bid and its deliverables are also, at the time of writing, still profiled on the website of the ACERWC. 
Comment is a means by which a treaty body 'distils its considered views on an issue which arises out of the provisions of the treaty whose implementation it supervises ... In essence the aim is to spell out and make more accessible the "jurisprudence" emerging from its work'.

But as Gerber et al. state, while General Comments do not legally bind states, they have acquired a more normative and prescriptive status than in the past: 'General Comments nonetheless play a substantive legal role in the elaboration of standards and possible future custom within the complex matrix of international law' (Gerber 2013: 9; see too Skelton, 2018: 395).

Gerber also discusses the functions of a General Comment (as they have evolved), such as that they have a forward-looking orientation, which seems to be especially important now as the Covid-19 virus infection rates subside, and States must start addressing the way(s) in which normality should resume.

In practice, General Comments can also function to serve as a benchmark in the assessment of periodic reports submitted to treaty monitoring bodies. Both the CRC Committee and the ACERWC routinely refer to their previous General Comments in dialogue with State Parties, as well as in their Concluding Observations. This is testimony to the more enduring function of General Comments, by comparison to other interventions such as press releases, Guiding Notes and so forth. Regular reference to the need for a "pandemic roadmap" to be developed and institutionalised at State level to ensure the least possible infringement of children's rights during any future pandemics, disasters or emergencies can serve valuable implementation goals, therefore.

It is also worth mentioning that over time, the process of developing General Comments has become more participative and inclusive. This is the case at the UN level, for instance in relation to the Committee on the Rights of the Child, but also those issued by the African Committee of Experts have routinely been taken through a vigorous validation process with participative workshops preceding their finalisation, accommodating both experts and country representatives, and children as well. Hence, the development of a General Comment on state responses to pandemics, emergencies and disasters could reveal a wealth of best practices and, conversely, illuminate steps which are counter productive or which violate children's rights. ${ }^{4}$

4 For instance, the experience of some countries (eg Kenya) in deinstitutionalising children in alternative care at the commencement of lockdown, where children were released without proper reintegration plans being in place. See, for instance: https://www.christianitytoday. $\mathrm{com} / \mathrm{ct} / 2 \mathrm{O} 2 \mathrm{O} /$ october-web-only/pandemic-orphanages-close-kids-return-home.html. Accessed 2 March 2021. 
Some of the detail that could form the basis of a General Comment could include the following principles and guidance:

- That State parties should prioritise reopening schools and take all possible measures to reopen safely. When schools are closed, traditional school feeding programmes should be adapted to provide take-home rations or cash transfers, so that the children who need it most continue to receive this vital source of support and food (UNICEF, 2O2O).

- That reopening schools safely should be effected as soon as is feasible, as school-based targeting and delivery of nutrition to children there is more cost effective and has been shown to yield substantial benefits in education and health outcomes. Leveraging the power of school feeding programmes to encourage children, especially girls and the vulnerable, to return to school post-crisis is important, as evidence shows that school feeding programmes can increase enrolment and attendance, especially for girls and disadvantaged children, and they can play a key role in getting children back to school and keeping them enrolled post crisis.

The pandemic has thrown into relief the need to upscale preparations for online, remote, radio and other forms of delivery of educational programmes. This should be undertaken before another pandemic or emergency strikes, and African State Parties might be exhorted to share with each other best practice and concrete tools to enable education to continue in difficult circumstances. Teacher training in edtech should now also become a priority. Programmes should be designed with a range of settings in mind, from urban slums to hard- to-reach rural settings. State parties should furthermore ensure that transitions to online learning do not exacerbate existing inequalities or replace student-teacher interaction. For instance, those enjoying private schooling rather than accessing the public school system should not be better placed to continue their education. The by now well-known slogan, "leave no-one behind", must be borne in mind in shaping all state responses to pandemics and emergencies.

In keeping with the overall concern of the African Children's Charter for the marginalised and vulnerable position of the girl child, getting girl children to return to school is critical. And, as the African Committee of Experts on the Rights and Welfare of the Child has recently opined, State Parties should '[a]dopt and implement policies and strategies for the retention of pregnant and married girls and their re-entry after delivery for pregnant girls' (ACERWC, 2021: 2).

Access to basic services, including health services, sexual and reproductive health services, birth registration and so forth must at all costs be preserved, to avoid a continuous violation of children's rights. Similarly, measures to 
mitigate and respond to the potential increase of GBV and harmful cultural practices in these unusual circumstances must be devised, preferably before emergency situations arise or develop. The African Committee enjoins that State Parties must ensure,

that sexual reproductive health services are not interrupted or deprioritized and funded during conflict, crisis, and other situations requiring humanitarian interventions, such as the Covid-19 pandemic. conflict, and displacement given the fact that humanitarian situations expose adolescents to various sexual abuses and that such services are essential and lifesaving (ACERWC, 2121: 2).

Along the same vein, the Committee advocates for adolescents to have access to basic sexual and reproductive health services in schools (such as menstrual hygiene materials), and for support to teenage pregnant girls as well as survivors of sexual abuse, to ensure that they have access to sexual reproductive health services including pregnancy follow-up. These have all been placed at enormous risk during the COVID-19 pandemic.

\section{Conclusion}

This article has sought to particularise the impact of COVD-19 for children's enjoyment of their rights in the African context. Demonstrably different considerations arise by comparison to children's experiences in the global north. The capacity of States to respond, and general access to digital technology, is also a differentiating factor. The CoviD-19 experience is not the first pandemic, epidemic or disaster on the continent, and it must be assumed that it will not be the last. Therefore, we argue that it would be a valuable contribution for the regional child's rights monitoring body to develop an authoritative guide to states parties in the form of a General Comment on state responses to upholding children's rights in the context of epidemics, pandemics and emergencies. This regional response would permit the guidance to focus on the specific vulnerabilities of categories of the African child, such as the girl child, girls at risk of sexual violence, children living on the street, children who experience food insecurity and so forth. It could highlight those Charter rights which are most at risk, and the nature of the state obligation in response.

Much as the focus in some quarters is turning to both a backward-looking inquiry as to what could have been done differently (or better) during the pandemic to minimise the risk of increasing children's rights violations, as well as a 
forward looking "roadmap" (the phrase currently in vogue in the United Kingdom, for instance), we propose that the process of formulating a General Comment for the African region would make an important contribution for the future.

\section{References}

\section{Journal Articles}

Akech. J., "Exacerbated inequalities: Implications of coviD-19 for the socio-economic rights of women and children in South Sudan", African Human Rights Law Journal $2020(20), 584-606$.

Anifowoshe, O., Aborode, A., Ayodele, T. et al, "Impact of CoviD-19 on Education in Sub-Saharan Africa", PrePrints 2020, 1-26.

Care, "Gender-Based Violence (GBV) and covid-19: The Complexities of Responding to 'The Shadow Pandemic', A Policy Brief 2020, 6.

Cucinotta. D. and Vanelli, M., "WHo Declares CoviD-19 a Pandemic", Acta Biomedica $2020(91(1)), 157-160$.

Dlamini, J., "Gender-Based Violence, Twin Pandemic to Covid-19" Critical Sociology 2020, $1-8$.

Duraku, Z. and Nagavci, M., "The impact of the Covid-19 pandemic on the education of children with disabilities", ResearchGate 2020,1-44.

Gerber, P. et al., "General Comment 16 on state obligations regarding the impact of the business sector on children's rights: what is its standing, meaning and effect", Melbourne Journal of International Law, 2013 (14), 93-128.

IFRC, "Prevention and response to Sexual and Gender-Based Violence in CoviD-19", Protection, Gender \& Inclusion (PGI) Technical guidance 2020, note 6.

Kamga, S., "COVID-19 and the inclusion of learners with disabilities in basic education in South Africa: A critical analysis", African Human Rights Law Journal (2020), $55^{8-583}$.

Mezmur, B. D., "Editorial: The African Children's Charter @3o: a distinction without a difference?" International Journal on Children's Rights 2020, 695.

Mittal, S., and Singh, T., "Gender-Based Violence During Covid-19 Pandemic: A MiniReview", Frontiers in Global Women's Health (2020) (1(4)), 1-7.

Onyango, M., Resnick, K. and Davis, A. et al., "Gender-Based Violence Among Adolescent Girls and Young Women: A Neglected Consequence of the West African Ebola Outbreak: Medical, Anthropological, and Public Health Perspectives", ResearchGate 2019, 121-132.

Parry, B. and Gordon, E., "The shadow pandemic: Inequitable gendered impacts of COVID-19 in South Africa", Wiley 2020, 1-12. 
Paschal, M. and Mkulu, D., "Online Classes during Covid-19 Pandemic in Higher Learning Institutions in Africa”, Global Research in Higher Education (2020) 3(3), $1-21$.

Roberton, T., Carter, E., Chou, V. et al., "Early estimates of the indirect effects of the COVID-19 pandemic on maternal and child mortality in low-income and middleincome countries: a modelling study", The Lancet (2020) 8, 901-9o8.

Saks, Ahmed et al., "Impact of the societal response to COVID-19 on access to healthcare for non-COVID-19 health issues in slum communities of Bangladesh, Kenya, Nigeria and Pakistan: results of pre-COviD and COVID-19 lockdown stakeholder engagements", BMJ Global Health (2020) 5(8), 1-17.

Skelton, A., "Child Justice in South Africa: Application of International Instruments in the Constitutional Court", International Journal on Children's Rights (2018) 26(3), 391-422.

Sloth-Nielsen, J., “The Protection of Children's Economic, Social and Cultural Rights under the African Children's Charter", in , L. Chenwi and , D. Chirwa, "Litigating socio-economic rights" (Cambridge University Press, 2016).

\section{Internet References}

ACERWC, “Guiding Note on Children's Rights during COvID-19”. Available at: https://www. acerwc.africa/guiding-note-on-childrens-rights-during-covd-19/. Accessed 1 March 2021.

ACERWC General Comments. Available at: https://www.acerwc.africa/generalcomments/.

African Union, "COVID-19 threatens to reverse progress in birth registrations: strategies for counter-actions". Available at: https://au.int/en/pressreleases/20200817/covid-19threatens-reverse-progress-birth-registrations-strategies-counter. Accessed 1 March 2021.

African Union, "No Name Campaign". Available at: https://au.int/en/newsevents/ 20200617/no-name-campaign. Accessed 1 March 2021.

Bhalla, N., "Covid-19 Threatens Kenya's Goal to End Female Genital Mutilation by 2022", Available at: https:/www.globalcitizen.org/en/content/CoviD-19-schoolclosures-end-fgm-in-kenya/. Accessed 18 December 2020.

"Education cannot wait": https://www.educationcannotwait.org/CoviD-19/. Accessed 1 March 2021.

Egbulem, C., "Opinion: Toward an infrastructure for gender-based violence response - lessons in the age of coviD-19". Available at: https://www.devex.com/news/ opinion-toward-an-infrastructure-for-gender-based-violence-response-lessons-inthe-age-of-covid-19-98185. Accessed ${ }_{15}$ December 2020.

European Network on Independent Living, "The Purpose and Use of UN Treaty Body General Comments". Available at: https://enil.eu/news/ 
the-purpose-and-use-of-un-treaty-body-general-comments /\#: :text=In\%2O other\%2 owords\%2C\%2owhile\%2othe, obligations\%2oenshrined\%2oin\%20 the $\% 20$ Convention. Accessed 4 March 2021.

Guardian World, "Huge FGM rise recorded in Somalia during coronavirus lockdown". Available at: https://www.theguardian.com/world/2020/may/18/fgm-risk-insomalia-heightened-by-coronavirus-crisis. Accessed 26 November 2020.

Hanekom, P., "COviD-19 exposes South Africa's digital literacy divide". Available at: https://mg.co.za/opinion/2O20-09-o8-COVID-19-exposes-south-africas-digitalliteracy-divide/. Accessed 11 December 2020.

Hodal, K., "Why coronavirus has placed millions more girls at risk of FGM". Available at: https://www.theguardian.com/global-development/2020/jun/16/coronavirusmillions-more-girls-risk-fgm. Accessed 12 December 2020.

Kandiah, K., "The Pandemic Sent Thousands of Orphans Back to Their Families. Let's Keep Them There". Available at: https://www.christianitytoday.com/ct/2020/ october-web-only/pandemic-orphanages-close-kids-return-home.html. Accessed 1 March 2021.

Newey, S. and Brown, W., "The 'perfect environment': how FGM is set to surge during the pandemic". Available at: https://www.telegraph.co.uk/global-health/womenand-girls/perfect-environment-fgm-set-surge-pandemic/. Accessed 31 December 2020.

Plan International, "How East Africa copes with CoviD-19 and the new layer of challenges it poses particularly to girls and young women". Available at: https://planinternational.org/eu/Humanitarian-priorities-for-girls-Eastern-Africa. Accessed 9 December 2020.

Polio Global Eradication Initiative: https://polioeradication.org/where-we-work/ sierra-leone/. Accessed 21 March 2021.

Reliefweb, "Impacts of COVID-19 on female genital cutting". Available at: https:// reliefweb.int/report/world/impacts-CoviD-19-female-genital-cutting. Accessed 12 December 2020.

Save the Children, "COvid-19 Places Half A Million More Girls At Risk of Child Marriage in 2020". Available at: https://www.savethechildren.net/news/COviD-19-placeshalf-million-more-girls-risk-child-marriage-202O. Accessed 12 December 2020.

UNFPA, "COVID-19: A Gender Lens". Available at: https://www.UNFPA.org/sites/default/ files/resource-pdf/COvID-19_A_Gender_Lens_Guidance_Note.pdf.AccessedıMarch 2021.

WHO, "COVID-19 significantly impacts health services for noncommunicable diseases". Available at: https://www.who.int/news/item/o1-06-2020-COvID-19-significantlyimpacts-health-services-for-noncommunicable-diseases. Accessed 1 March 2021.

Zuzile, M., 'Lockdown leaves thousands of newborns without birth certificates'. Available at: https://www.timeslive.co.za/news/south-africa/2020-05-15-lockdown- 
leaves-thousands-of-newborns-without-birth-certificates/. Accessed 1 March 2021.

\section{Reports}

Care, "Gender-Based Violence (GBV) and covid-19: The Complexities of Responding to "The Shadow Pandemic", A Policy Brief (2020), 1-16.

eLearning Africa, "The Effect of COVID-19 on Education in Africa and its Implications for the Use of Technology", (2O2O), 1-80.

Girls Not Brides, "Covid-19 and Child, Early and Forced Marriage: An Agenda for Action", (2020), 1-6.

Human Rights Watch, "Impact of covid-19 on Children's Education in Africa" (31 August-4 September 2020), 1-9.

Human Rights Watch, "The Education Deficit: Failures to Protect and Fulfil the Right to Education in Global Development Agendas" (2016), 1-102.

Mbulanheni, R., "Africa must bridge digital divide to adapt to e-learning technology" UCT Study (2020), $1-2$.

McAleavy, T., Joynes, C., Gibbs, E. et al., "Report Overview of emerging country-level response to providing continuity under COVID-19 What steps are being taken to reach the most disadvantaged students during the period of CoviD-19 school closure?" (2020), 8.

Orchid Project, "Impacts of COVID-19 on female genital cutting" (2O2O), 1-24.

Plan International, "Under Siege: Impact of covid 19 on girls in Africa" (Addis Ababa, 2020), 1-38 (Plan International B).

Plan International, "African Girls in the Covid-19 Pandemic" (2020), 4 (Plan International C).

Save the Children International, "Protect a generation: the impact of CoviD-19 on children's lives" (2O2O).

UNFPA and UNICEF, "Child Marriage in Covid-19 contexts: Disruptions, Alternative Approaches and Building Programme Resilience" (2O20), 1-9.

UNFPA-UNICEF, "COVID-19 Disrupting SDG 5·3: Eliminating Female Genital Mutilation" (2O20), 1-6.

UNICEF a, "All Means All - How to support learning for the most vulnerable children in areas of school closures" (2O2O), 1-4.

UNICEF b, "COVID-19 - GBV Risks to Adolescent Girls and Interventions to Protect and Empower them", (2O2O), 1-4.

UNICEF c, "COVID-19 - GBV Risks to Adolescent Girls and Interventions to Protect and Empower them" (2020) 1. 
UNICEF - Innocenti Centre for Research, "COVID-19: Effects of school closures on foundational skills and promising practices for monitoring and mitigating learning loss", Innocenti Working Paper No. 2020-13, Florence (2020).

United Nations, "Policy Brief: Education during Covid-19 and beyond" (August 2020), $1-26$.

\section{UN Documents}

Abidjan Principles on the Right to Education (2019).

UN Committee on Economic, Social and Cultural Rights General Comment No. 3, "The Nature of States Parties' Obligations" (E/1991/23).

UN crc Committee General Comment No.15 on the Right of the Child to the Enjoyment of the Highest Attainable Standard of Health (Art. 24) (2013) CRC/C/GC/15.

UN CRC Committee General Comment No. 19 (public budgeting for the realisation of children's rights), CRC/C/GC/19.

\section{Cases}

Equal Education and others v. Minister of Basic Education (case 22588/2020). SA Childcare (Pty Ltd) v. Minister of Social Development and others (case 36962/2020).

\section{African Committee of Experts on the Rights and Welfare of the Child documents}

African Committee of Experts on the Rights and Welfare of the Child, "Outcome statement of the Day of General Discussion on the Sexual Reproductive Health and Rights of Adolescents" (issued 21 March 2021).

African Committee of Experts on the Rights and Welfare of the Child, "Joint General Comment of the African Commission on Human and Peoples' Rights (ACHPR) and the African Committee of Experts on the Rights and Welfare of the Child on ending child marriage" (2017).

Africa Committee of Experts on the Rights and Welfare of the Child, "General Comment No. 5 on General Measures of Implementation and systems strengthening for child protection" (2019).

African Committee of Experts on the Rights and Welfare of the Child, "Decision on the communication submitted by the Institute for Human Rights and Development in Africa and the Open Society Justice Initiative (on behalf of children of Nubian descent in Kenya) against the government of Kenya" (Communication: No. Com/oo2/2009).

African Committee of Experts on the Rights and Welfare of the Child, "Legal and Human Rights Center and Center for Reproductive Rights (on behalf of Tanzanian girls) v. United Republic of Tanzania (Communication No: oo12/Com/oo1/2019: Decision on Admissibility No: 001/2020). 
African Commission on Human and Peoples' Rights

Maputo Protocol to the African Charter on Human and Peoples' Rights, 2003.

CRC Committee documents

General Comment on Violence Against Children in 2013 (CRC/C/GC/13).

General Comment No. 19 on public budgeting for the realisation of children's rights (CRC/C/GC/19). 